\title{
Science mapping in the research of higher education internationalisation from 2013 to 2018 in Asia: publications, regional networking and future trends
}

\author{
Yang Can \\ Jinhua Polytechnic, Jinhua, China, and \\ Angela Yung Chi Hou \\ National Chengchi University, Taipei City, Taiwan
}

\begin{abstract}
Purpose - The advance in higher education in Asian countries is of major interest because it reveals increasing global political and cultural influence in recent years. The review explores the characteristics of publications from 2013-2018 concerned with the internationalisation of higher education in Asia. The study aims to analyse the current trajectory, including the size, growth trends, and regional networking of this domain, with a goal of identifying the influential journals, authors, and documents, as well exploring the thematic structure and topical issues and trends of this domain.

Design/methodology/approach - 241 Scopus-indexed documents were selected and reviewed using a quantitative descriptive way. These documents were analysed by VOS viewer software.

Findings - The results show the most topical issues and trends concern about "Asian immigration and mobility", "transnational education", "international students and acculturation", and "international branch campuses". Seven main schools of thought were identified and are clearly explained herein, which provides a baseline for future research for new scholars.

Social implications - The present study suggests that trans-regional cooperation is the future of internationalisation in higher education. Asian scholars are recommended to increase cooperation and exchanges with each other, expand channels of contact, further understand and optimise their own advantages, achieve win-win cooperation and make Asia's voice heard in the world in higher education field.

Originality/value - This bibliometric review can predict the main trends in higher education internationalisation in the future and encourage implication of interdisciplinary research in higher education internationalisation.
\end{abstract}

Keywords Bibliometric review, Science mapping, Higher education internationalisation, Asia

Paper type Research paper

\section{Introduction}

Over the past decades, "internationalisation" in higher education has been perceived as a world phenomenon, especially since the late 1980s, and has developed into an educational vision that provides the global community with an education that meets the current needs (Altbach, 2002; Bennell and Pearce, 2003; Gacel-Ávila, 2005). The content and context have

(C) Yang Can and Angela Yung Chi Hou. Published in Higher Education Evaluation and Development. Published by Emerald Publishing Limited. This article is published under the Creative Commons Attribution (CCBY 4.0) licence. Anyone may reproduce, distribute, translate and create derivative works of this article (for both commercial and non-commercial purposes), subject to full attribution to the original publication and authors. The full terms of this licence may be seen at http://creativecommons. org/licences/by/4.0/legalcode

Funding: This research did not receive any specific grant from funding agencies in the public, commercial or not-for-profit sectors. 
HEED

15,1

\section{6}

Figure 1.

Seven broad themes on the issues of internationalisation in higher education been changed according to Knight (1993); internationalisation of higher education is "the process of integrating an international/intercultural dimension into the teaching, research, and service functions of the institution" (p. 21). Later, she updated her research by integrating transnational, borderless and cross-border education into the global context (Knight, 1993).

Internationalisation is a continuous process, involving all aspects of higher education, particularly in teaching and learning. Yet, over the past decade, research on the internationalisation of higher education has made significant progress both in quantity and quality (Kehm and Teichler, 2007). Currently, the field is reasonably diversified (Ghasempoor et al., 2011; Hudzik, 2011; Streitwieser and Ogden, 2016). Earlier, Kehm and Teichler (2007) identified seven broad trends on the issues of internationalisation in higher education, which are as follows: mobility, cooperation and competition, national policy, knowledge transfer, substance of teaching, learning, institutional strategies and mutual influences of higher education systems. This chimes with the three trends of "mobility, co-operation and competition, and national policy" outlined by Knight (2003) (see Figure 1). It shows that the research themes, domains and methods of higher education internationalisation have become more extensive in the global context. Although different contexts may show different interests in research of higher education internationalisation, the above general trends can also be identified globally (Altbach et al., 2009; Kehm and Teichler, 2007). Asia is no exception.

Since the 1980s, Asian scholars started to pay attention to the development of higher education internationalisation and outcomes. At the "International Symposium on Higher Education in Asia" in 1986, Kazuyuki, Professor of Research Institute for Higher Education at Hiroshima University, Japan, proposed three criteria for measuring the internationalisation of higher education, including universality, communicativeness and openness. Moreover, Mok (2007) called for reflection on internationalisation of higher education in Asia and addressed that international universities did not necessarily follow the Western models. Asian scholars should be more confident in their systems and proud of their culture and

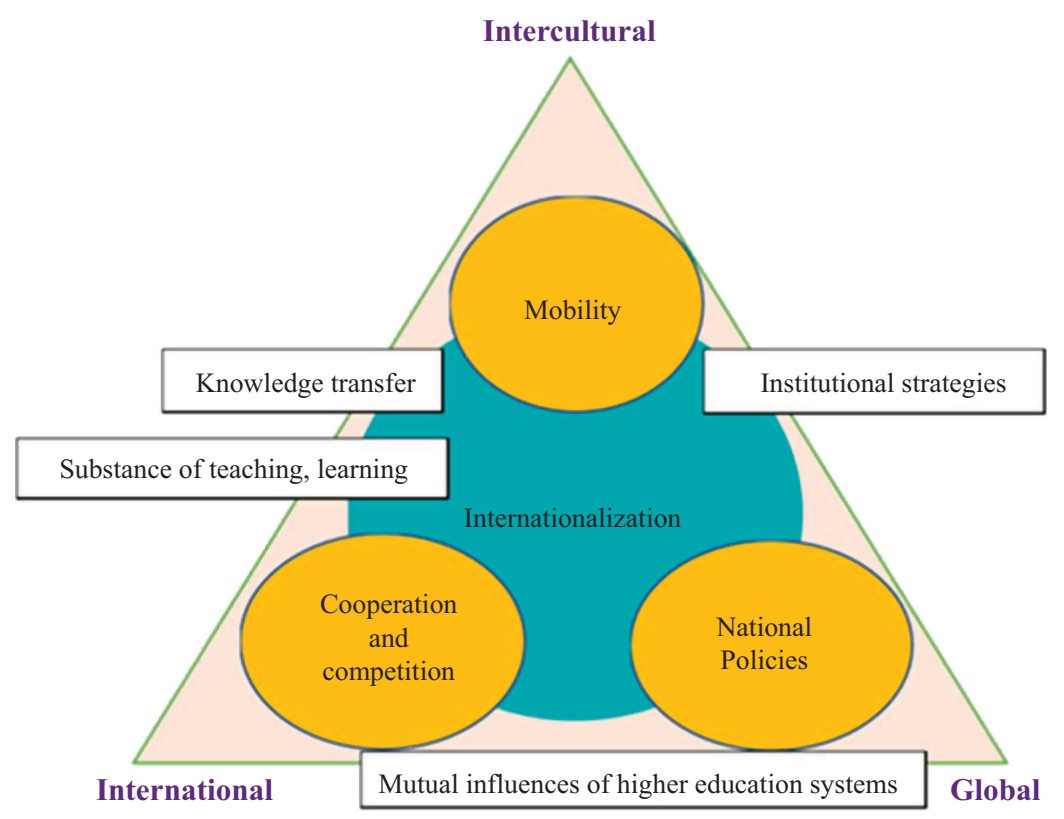


traditions. They not only need to internalise academic system, but also to cultivate and develop their own international paradigm with Asian characteristics.

Sin (2011) had analysed 8,140 articles in his research about trends in internationalisation of seven journals between 1980 and 2008; he concluded that Asian regions such as Singapore and Taiwan contributed greatly in the past years and domestic cooperation is the main type of authorship pattern. Jung and Horta (2013) had analysed 514 articles published between 1980 and 2012 and concluded that the higher education research in Asia is in its incubation period, closely following the trend of the global higher education research.

Due to rapid economic growth and talent mobility, higher education in Asia has been moving towards a comprehensive internationalisation phase. Most nations have put forward the goal of reforming their educational systems, becoming the education hubs, as well as building world-class universities throughout several internationalisation strategies. In order to further observe the current development trend of higher education in Asia, the present study reviewed 241 journal articles collected from SCOPUS and constructed a framework of the field of higher education internationalisation in recent five years, from 2013 to 2018, by applying VOSviewer bibliometric analysis software.

This study is expected to provide a better understanding for scholars entering this field in terms of co-citation and keyword co-occurrence analysis of journal articles published in the Asian region over the last 5 years. The main research purposes were as follows:

(1) To identify the development trajectory of higher education internationalisation in Asia.

(2) To examine the influential journals, authors and documents that have examined higher education internationalisation in the Asian region over the last 5 years.

(3) To explore the thematic structure and topical issues and trends that researchers are concerned about regarding higher education internationalisation in the Asian region.

\section{Literature review}

The global demand for international higher education is growing faster than ever due to massification, privatisation and academic competition (Bohm et al., 2002; Marginson, 2011). As Altbach (1999) observed, "the current wave of internationalism is driven by profit. The goal is to meet market demand and create a niche market for "educational products"' (p. 4). In recent years, internationalisation has been recognised by higher education institutions as one of the key means to improve quality. Higher education in various countries has emphasised the importance of expanding openness and strengthening exchanges. Since 2000, Asia has established major initiatives to increase its visibility in the global education market. It has strived to build partnerships with leading institutions around the world and develop educational centres to improve its global competitiveness (Mok and Yu, 2013). Several universities in Japan, South Korea, Singapore, Mainland China, Hong Kong and Taiwan ranked top institutions in the world (Wang, 2015).

Asia has not only actively opened up their education markets in various forms to the outside world but has also encouraged universities to develop academic partnerships and links with foreign institutions (Palmer et al., 2011). In addition to developing collaborative programmes and attracting more international students, scholars have started to pay attention to higher education research and have jointly published research papers in Asia. A steady growth in the number of publication outputs has been found, both in specialised and nonspecialised journals, in the field of higher education research in Asia, with the latter having a notably faster rate of growth. Yet, lack of connection among Asian researchers is still observed, often those who work in isolation. As Horta and Jung (2014) suggested, 
HEED

15,1

researchers in Asia must strengthen their engagement with others and exchange their ideas and knowledge with the global academic community.

The upgrading and expansion of higher education in Asia has made it an interlocutor, collaborator and partner of universities in other parts of the world. The more opportunities and challenges emerged, the more concerns and issues are addressed by policymakers as well as researchers. The study by Shin and Harman (2009) indicated five major challenges in the 21st century facing higher education systems in the Asian region, including massification, privatisation, accountability and governance, internationalisation, ranking and world-class universities. Those challenges also became debatable topics worthy of examination in Asia. Postiglione (2011) also published several researches related to economic impacts on student enrolment in higher education, the quality of private sectors and the shrinkage of the graduate employment market. Horta and Jung (2014) revealed themes in two distinct groups of thought in their research. One group identified as the group of teaching and learning, including the themes of course design, teaching and learning, as well as student experience. The other identified as the group of policy, including system policy, institutional management, academic work, quality, knowledge and internationalisation. Accordingly, the tendency over issues and themes in higher education research in Asia is shifting and moving to becoming more diversified.

\section{Methodology}

Science mapping was adopted as the main method of this study. In general, science mapping is a process of domain analysis and visualisation in the field of bibliometrics (Morris and Van der Veer Martens, 2008; van Eck and Waltman, 2017). Chen Yue and Liu Zeyuan (2005) pointed out that science mapping is a relatively new research method in scientometrics and information metrology in recent years, which can reveal not only the knowledge source and its development rule but also express the knowledge structure relationship and evolution rule in related fields with graphics. It aims at "displaying the structural and dynamic aspects of scientific research" (Braam et al., 1991, p. 233), and it can represent the main themes and the relationships between them in the domain.

The workflow of science mapping analysis typically consists of the following eight steps (Börner et al., 2003; Cobo et al., 2011): data retrieval, preprocessing, network extraction, network normalisation, mapping, analysis, visualisation and interpretation (see Figure 2). VOSviewer is visualisation software developed by Van Eck and Waltman at Science and Technology Research Center of Leiden University in the Netherlands and has unique advantages in clustering technology and map drawing which can draw co-occurrence maps of authors, citations and keywords.

\subsection{Data retrieval and extraction}

The study analyses all studies related to higher education internationalisation of Asia published from 2013 to 2018. Some bibliometricians pointed out that Scopus provides a broader coverage than SSCI (WOS) database, and more complete data that can be used for bibliometric analysis than Google Scholar (Zupic and Cater, 2015). Thus, The SCOPUS database was selected for data retrieval due to its wide coverage of research outputs worldwide.

First, searches for "internationalization" and "Asia” led to 986 articles initially. Secondly, the source types of documents are limited to journals. Books, conference proceedings, series of books, trade publications and reports were excluded from the study. Then, in order to precise research scope, we limit the document type to final article, limit the subject area to social sciences and limit the document language to English only. After screening, 473 
Science

mapping

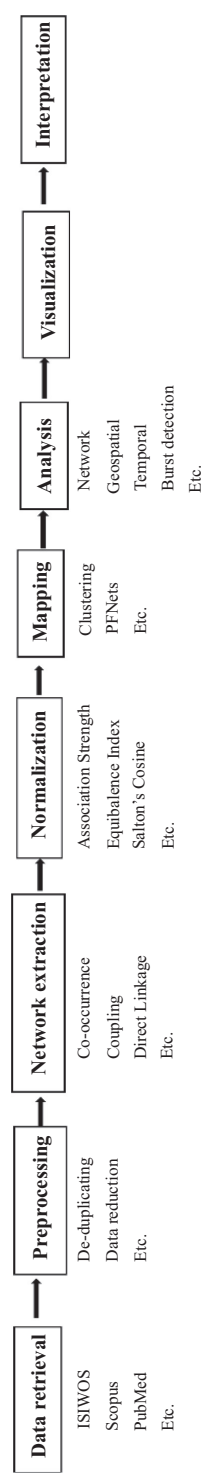

39

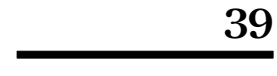


HEED

15,1

40

references were included in the next analysis. Thirdly, when reading the review summary, two types of documents are excluded from the study: those that focus primarily on language teaching and those that do not focus on "internationalization" as a topic. As a result of the above screening, 241 articles were selected and exported as CSV (comma-separated values format).

The exported data included all available citation information (e.g. the authors, document title, source title, citation count, year and volume), bibliographical information (e.g. the affiliations, serial identifiers and publisher), abstract, keywords and other information related to the references.

\subsection{Analysis and visualisation}

In addition, author co-citation analysis (ACA) was used to identify the academic structure of this knowledge domain by tracking the relationship between two authors, and keyword co-occurrence analysis was constructed to present the academic systems and trends of higher education internationalisation in Asia. VOSviewer software was adopted as the analysis tool to visualise the results. VOSviewer is a tool for "displaying large bibliometric maps in an easy-to-interpret way" (Van and Waltman, 2010).

\section{Results}

\subsection{Global trajectory of higher education internationalisation research}

Initially, in order to see the global trajectory of higher education internationalisation, a total of 1,179 articles were retrieved using keywords "interntaionlisation" OR "interntaionalization". The number of publications grew steadily from 2015, averaging 200 publications each year, and the number reached its peak in 2018 with 243 publications (see Figure 3). The articles were reviewed in terms of relevance according to theme.

As we can see from Figure 4, the top ten countries and regions in this database, according to scholarly output, are the UK (169), the USA (159), Australia (105), China (46), Canada (39), Spain (36), Hong Kong (28), Germany (23), Japan (23) and Finland (22). As Figure 4 shows, most of the articles were produced in the UK, the USA and Australia. These three countries

\section{Documents by year}

Figure 3.

Worldwide development trajectory of higher education internationalisation
260

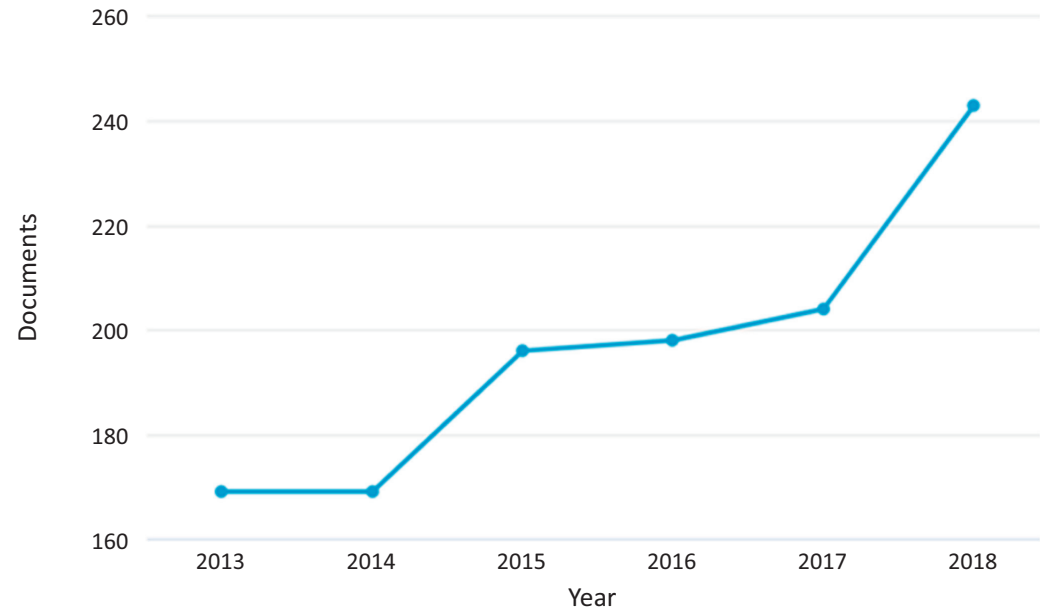




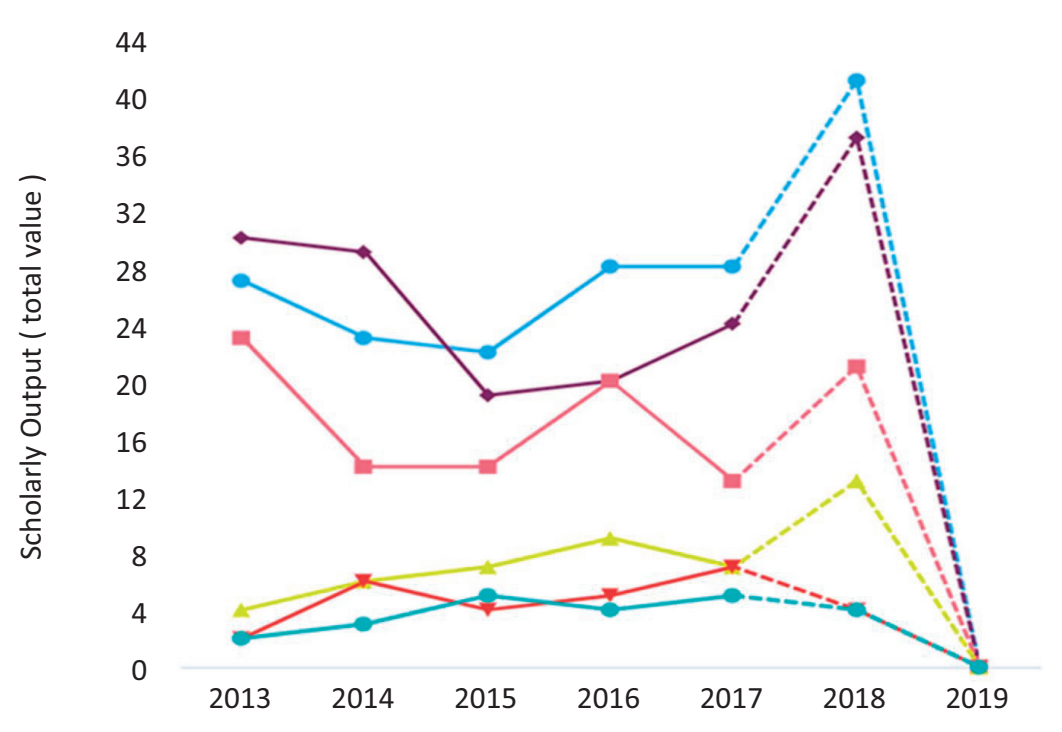

Note(s): •United Kingdom • United States • Australia - China •Hong Kong • Japan
Science mapping

41

Figure 4.

Global distribution of the literature on the internationalisation of higher education

played a major role and accounted for almost half of the whole output of the research on higher education internationalisation. Asian countries and regions like China, Hong Kong and Japan followed far behind, accounting for just $11 \%$ of the total research output. This result demonstrates a growing interest in the research of higher education internationalisation globally. However, the higher education contexts as well as level of maturity and quality of institutions in regions have led to different focuses and priorities in the internationalisation of higher education (Horta and Jung, 2014). As Horta and Jung (2014) argued, "the rise of higher education in Asian countries is of major interest as it is wielding increasing political and cultural influence globally" (p. 2). Therefore, conducting an in-depth analysis according to geographical location, particularly the Asian region, was noteworthy.

\subsection{Current trajectory of higher education internationalisation research in Asia}

Table 1 shows the publication output of the top ten countries and regions in this domain. As noted, the USA, the UK and Australia rank at the top by number of publications, which not

\begin{tabular}{llccc}
\hline Rank & Country and territories & Scholarly output & Citation count & Citation per publication \\
\hline 1 & United States & 44 & 213 & 4.89 \\
2 & United Kingdom & 32 & 339 & 10.59 \\
3 & Australia & 31 & 222 & 7.19 \\
4 & Hong Kong & 29 & 202 & 6.97 \\
5 & Tai wan & 25 & 158 & 6.36 \\
6 & China & 20 & 66 & 3.3 \\
7 & Singapore & 17 & 127 & 7.47 \\
8 & South Korea & 16 & 86 & 5.44 \\
9 & Japan & 15 & 73 & 4.87 \\
10 & Malaysia & 14 & 48 & 3.43
\end{tabular}

Table 1.

Top ten countries and territories by scholarly output 
HEED

15,1

42

only means that they have published many more articles than other countries but also suggests that they have played an important role in the Asian region over the last 5 years regarding the internationalisation of higher education. However, with the rapid economic growth in Asian societies, the quantity and quality of research in higher education have continuously improved and attracted considerable attention from around the world. In particular, Hong Kong (29), Taiwan (25), China (20), Singapore (17) and South Korea (16) made significant contributions to the field, altogether accounting for $44 \%$ of overall publications.

\subsection{Influential journals, authors and documents}

We analysed journal rankings to ensure that all influential and significant journals were included in the study. Table 2 presents the top ten leading journals ranked by the Scopus Citation Impact. They published 76 of the articles retrieved for this study, comprising approximately $32 \%$ of the total outputs. These journals have become a powerful engine in this domain. According to journal rank, eight of the top ten journals were classified as a firsttier Q1 journal. Meanwhile, Asia Pacific Education Review and Asia Pacific Journal of Education were defined as second-tier Q2 journals. Asia Pacific Education Review is a peerreviewed journal produced by Seoul National University, while Asia Pacific Journal of Education is produced by the National Institute of Education in Singapore. Interestingly, both of these Asian-indexed journals were highly cited (334 and 169, respectively), in contrast to several Q1 journals.

In addition, most of the journals were organised into education subject area. Notably, Discourse was identified as an interdisciplinary journal with three subjects, including education, linguistics and language, whereas Higher Education Policy was categorised into the subject areas of sociology and political science education. As the main carriers of the subject area and the commanding point of knowledge innovation, these leading academic journals have had great influence on the research domain in both the quantity and quality of the articles published.

Regarding the most productive authors in Asia, most were from Hong Kong, Taiwan and Singapore. In total, authors from these countries have published 78 articles in the last 5 years. The top five leading authors, along with the number of citation counts, are Collins, Francis L. from New Zealand (124); Hou, A.Y.C. from Taiwan (68); Rienties, B. from the UK (59); Mok,

Table 2 .
Leading journals on the

\begin{tabular}{|c|c|c|c|c|c|}
\hline Rank & Source & Domain & $\begin{array}{l}\text { Number of } \\
\text { docs }\end{array}$ & $\begin{array}{l}\text { Scopus } \\
\text { cites }\end{array}$ & $\begin{array}{l}\text { Scopus } \\
\text { quartile }\end{array}$ \\
\hline 1 & Higher Education & Education & 14 & 760 & Q1 \\
\hline 2 & Studies in Higher Education & Education & 11 & 488 & Q1 \\
\hline 3 & $\begin{array}{l}\text { Asia Pacific Education } \\
\text { Review }\end{array}$ & Education & 8 & 334 & Q2 \\
\hline 4 & Comparative Education & Education & 9 & 287 & Q1 \\
\hline 5 & $\begin{array}{l}\text { Journal of Studies in } \\
\text { International Education }\end{array}$ & Education & 10 & 234 & Q1 \\
\hline 6 & $\begin{array}{l}\text { Asia Pacific Journal of } \\
\text { Education }\end{array}$ & Education & 7 & 169 & Q2 \\
\hline 7 & Asia Pacific Viewpoint & Development & 5 & 157 & Q1 \\
\hline 8 & $\begin{array}{l}\text { Higher Education Research } \\
\text { and Development }\end{array}$ & Education & 4 & 133 & Q1 \\
\hline 9 & Discourse & $\begin{array}{l}\text { Education linguistics } \\
\text { and language }\end{array}$ & 4 & 116 & Q1 \\
\hline 10 & Higher Education Policy & $\begin{array}{l}\text { Sociology and political } \\
\text { science }\end{array}$ & 4 & 102 & Q1 \\
\hline
\end{tabular}
internationalisation of higher education in Asia, ranked by Scopus 10 citation impact 
K.H. from Hong Kong (59); and Yeoh, B.S.A. from Singapore (51) Interestingly, Rienties from the UK and Yeoh from Singapore did not publish as many papers as others, but their papers had a noticeably higher number of citations (59 and 51, respectively) (see Table 3).

An analysis of the top 20 authors' affiliations revealed that $85 \%$ of them were from leading universities. Overall, $70 \%$ of the universities are public research institutions, and thus we can conclude that the public universities dominate the contribution to this domain. Five of the affiliations are liberal arts type institutions that have published a notable number of articles in the social sciences subject area: The Education University of Hong Kong (37.9\%), University of Waikato (30\%), Indiana University of Pennsylvania $(26.2 \%)$, Hong Kong Lingnan University $(23 \%)$ and Open University in the UK $(20 \%)$. By contrast, other universities such as Fu Jen Catholic University, University of Chile and the University of Hong Kong only published 3.5, 4.6 and $7.2 \%$ of the total number of papers in the social sciences domain, respectively (see Table 4).

Academic networking refers to scholars collaborating on and co-authoring a joint research paper. Only 45 of the 426 authors reviewed here were not connected to each other. The map shows that the authors with the highest degree of collaboration are Hou, A.Y.C.; Chen, H.J.; Morse, R.; Chiang, C.L.; Ince, M.; Chan, Y.; Wang, W.; and Tsai, S (see Figure 5). A few collaborations between the key nodes existed, but the connections remained loose. This finding corroborates the argument made by Jung and Horta (2013). In short, higher education research is highly dependent on a small number of isolated scholars, instead of large research groups or teams.

Regarding the most influential articles from 2013 to 2018, a paper published by a UK scholar, which focused on global rankings, has been cited the most (Table 5). The top three influential papers published by Asian authors were from South Korea, Hong Kong and Taiwan. Mok, K.H. and Hou, A.Y.C. were the most productive authors, as shown in Table 5.

Four of the top ten papers focused on the topic of international students, which was associated with incentives and desire for mobility, social and cultural learning relations and cross-border learning experiences within and without the Asian region (Collins et al., 2014;

\begin{tabular}{lllcrr}
\hline Rank & Author & Nation & Document & Scopus cites & Citation per publication \\
\hline 1 & Collins, F.L. & New Zealand & 8 & 124 & 15.75 \\
2 & Hou, A.Y.C. & Tai Wan & 7 & 68 & 9.71 \\
3 & Rienties, B. & United Kingdom & 3 & 59 & 19.67 \\
4 & Mok, K.H. & Hong Kong & 7 & 59 & 8.57 \\
5 & Yeoh, B.S.A. & Singapore & 3 & 51 & 6.29 \\
6 & Ho, K.C. & Singapore & 7 & 43 & 20.50 \\
7 & Bryant, D.A. & Hong Kong & 2 & 41 & 12.33 \\
8 & Ahmad, S.Z. & United Arab & 3 & 37 & 9.00 \\
9 & Lee, J.T. & United Kingdom & 4 & 36 & 7.00 \\
10 & Yonezawa, A. & Japan & 5 & 35 & 11.33 \\
11 & Morse, R. & United States & 4 & 34 & 17.00 \\
12 & Chiang, C.L. & Tai Wan & 3 & 34 & 7.25 \\
13 & Byun, K & Korea & 2 & 34 & 13.50 \\
14 & Horta, H & Hong Kong & 4 & 29 & 5.75 \\
15 & Chen, H.J. & Tai Wan & 2 & 27 & 7.00 \\
16 & Jung, J. & Hong Kong & 4 & 23 & 8.50 \\
17 & Ince, M. & United Kingdom & 3 & 21 & 6.50 \\
18 & Buchanan, F.R. & United States & 2 & 17 & 4.00 \\
19 & Celis, S. & Chile & 2 & 13 & Top 20 highly cited \\
20 & Chan, S.J. & Tai Wan & 3 & 12 & authors from 2013 \\
& & & & & to 2018 \\
\hline
\end{tabular}




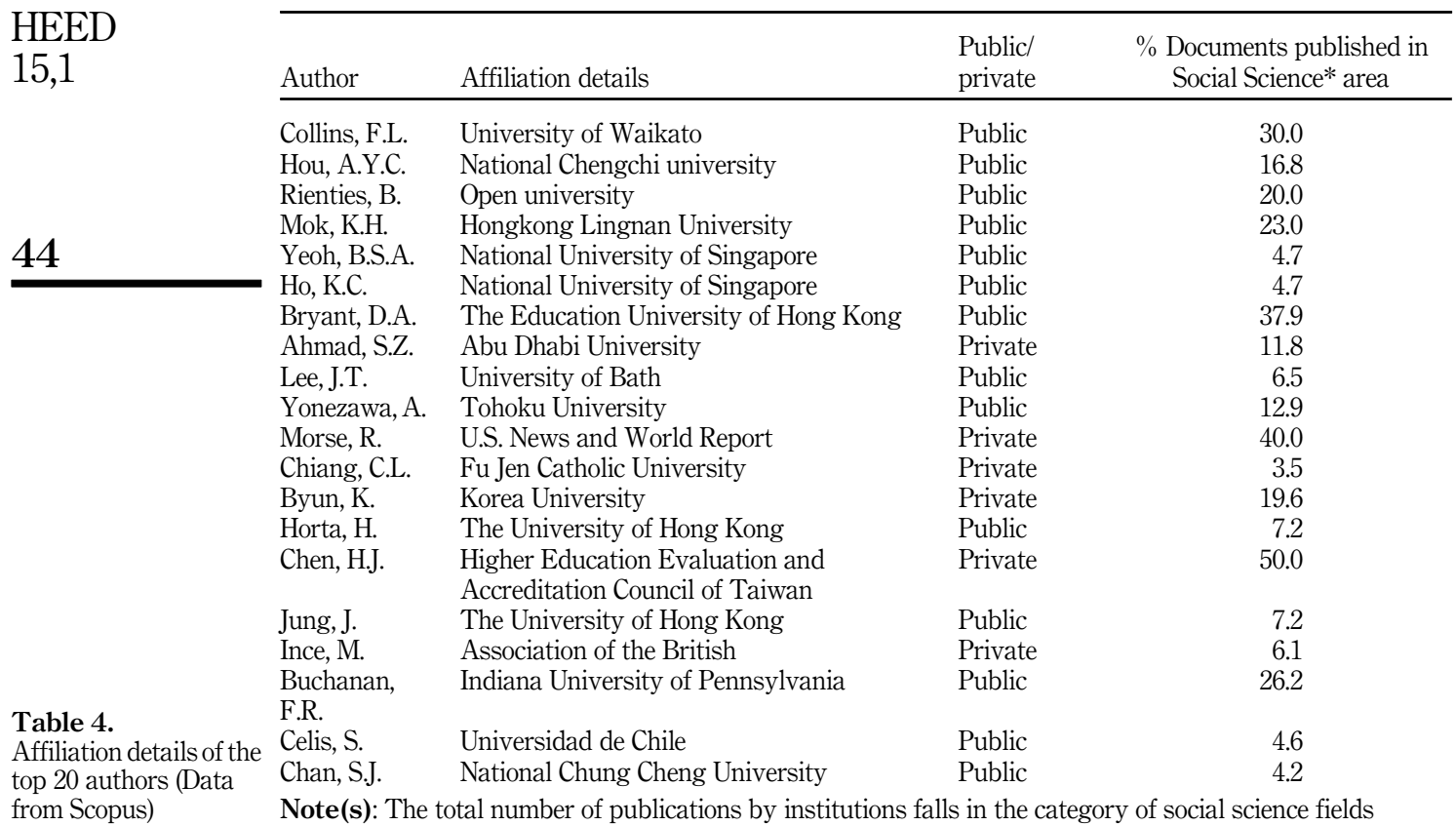

Houshmand et al., 2014; Jon et al., 2014; Rienties et al., 2013). The articles related to university rankings, quality assurance agencies, cultural national identities, employment and emerging internationalisation models employed multi-research approaches, including case studies, surveys and semi-structured qualitative interviews. One article written by Rienties employed a large-scale survey and applied multiple regression quadratic assignment procedures for analysis (Rienties et al., 2013).

Figure 5.

Co-authorship network in higher education internationalisation research

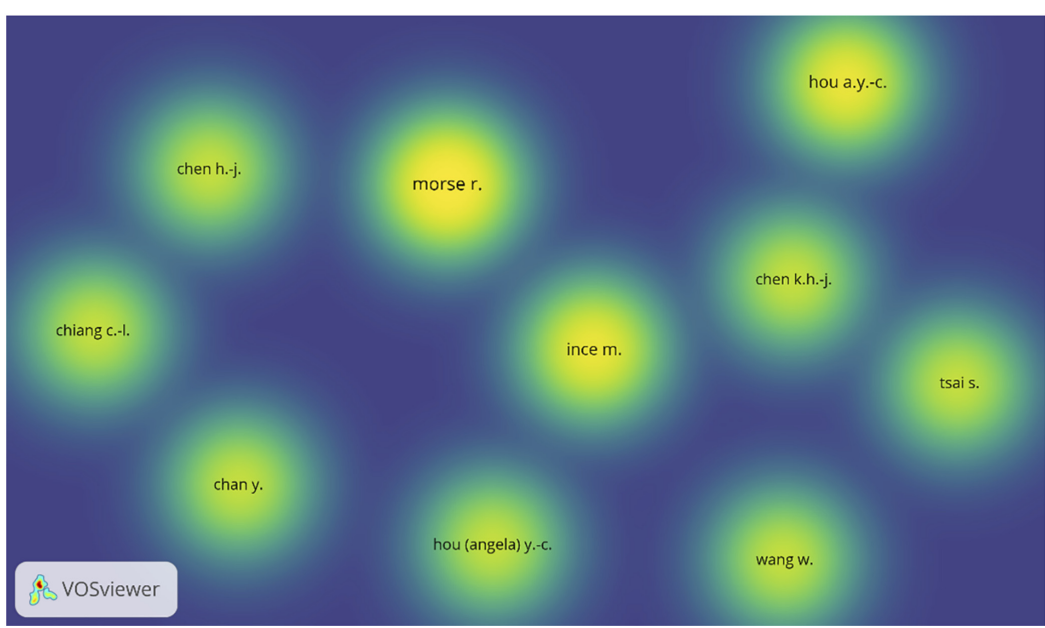




\begin{tabular}{|c|c|c|c|c|c|}
\hline Rank & Document & Authors & Society & $\begin{array}{l}\text { Scopus } \\
\text { cites }\end{array}$ & $\begin{array}{l}\text { Science } \\
\text { mapping }\end{array}$ \\
\hline 1 & $\begin{array}{l}\text { Global geographies of higher education: The perspective } \\
\text { of world university rankings }\end{array}$ & $\begin{array}{l}\text { Jöns and } \\
\text { Hoyler }\end{array}$ & UK & 86 & \\
\hline 2 & $\begin{array}{l}\text { Mobility and desire: International students and Asian } \\
\text { regionalism in aspirational Singapore }\end{array}$ & Collins et al. & $\begin{array}{l}\text { New } \\
\text { Zealand }\end{array}$ & 41 & \\
\hline 3 & $\begin{array}{l}\text { Understanding social learning relations of international } \\
\text { students in a large classroom using social network } \\
\text { analysis }\end{array}$ & Rienties et al. & UK & 39 & 45 \\
\hline 4 & $\begin{array}{l}\text { Emerging internationalisation models in an uneven } \\
\text { global terrain: Findings from a global survey }\end{array}$ & Maringe et al. & $\begin{array}{l}\text { South } \\
\text { Africa }\end{array}$ & 28 & \\
\hline 5 & $\begin{array}{l}\text { The emergence of a regional hub: Comparing } \\
\text { international student choices and experiences in South } \\
\text { Korea }\end{array}$ & Jon et al. & $\begin{array}{l}\text { South } \\
\text { Korea }\end{array}$ & 28 & \\
\hline 6 & $\begin{array}{l}\text { Issues surrounding English, the internationalisation of } \\
\text { higher education and national cultural identity in Asia: A } \\
\text { focus on Japan }\end{array}$ & Le Phan & Australia & 24 & \\
\hline 7 & $\begin{array}{l}\text { Massification of higher education, graduate employment } \\
\text { and social mobility in the Greater China region }\end{array}$ & Mok, K.H. & $\begin{array}{l}\text { Hong } \\
\text { Kong }\end{array}$ & 24 & \\
\hline 8 & $\begin{array}{l}\text { Excluded and avoided: Racial microaggressions } \\
\text { targeting Asian international students in Canada }\end{array}$ & $\begin{array}{l}\text { Houshmand } \\
\text { et al. }\end{array}$ & Canada & 24 & \\
\hline 9 & $\begin{array}{l}\text { Quality in cross-border higher education and challenges } \\
\text { for the internationalization of national quality assurance } \\
\text { agencies in the Asia-Pacific region: the Taiwanese } \\
\text { experience }\end{array}$ & Hou, A,Y.C. & Tai Wan & 23 & \\
\hline 10 & $\begin{array}{l}\text { experience } \\
\text { Deploying the post-colonial predicaments of researching } \\
\text { on/with "Asia" in education: A standpoint from a rich } \\
\text { peripheral country }\end{array}$ & Takayama & Australia & 23 & $\begin{array}{r}\text { Table } 5 . \\
\text { Top ten highly cited } \\
\text { articles from } 2013 \\
\text { to } 2018\end{array}$ \\
\hline
\end{tabular}

\subsection{Thematic structure of research in higher education internationalisation in Asia}

For this research problem, author co-citation analysis (ACA) is carried out, which has been widely used in knowledge mapping of different disciplines. We used the VOSviewer for our analysis, because it not only calculates the number of co-citations of authors but also creates a "citation map" based on the similarities between the authors' studies to see how the authors relate to each other, how often they publish and how they cite each other across a range of similar topics. s (Nerur et al., 2008). The map visualises how their works have been grouped into different intellectual themes and cited by others (Figure 6). Each node represents a different author, and the larger the node, the more times the author is referenced and the greater the impact. The density of "links" between authors reflects the number of times one author is cited jointly by the other. The map also divides the authors into "clusters" of different colours representing different schools of thought. These different schools reflect the common theoretical viewpoints and research directions of the author group.

As shown in Figure 6, the top ten highly co-cited authors were Knight, J. (181); Mok, K.H. (147); Altbach, P.G. (131); Marginson, S. (130); Yang, R. (65); Welch, A. (57); De Wit, H. (52); Huisman, J. (48); Huang, F. (47); and Teichler, U. (45).

The map shows seven "schools of thought" according to different clusters, identified by colour (i.e. red, yellow, blue, light blue, purple, green and orange). The first cluster (red) represents 32 scholars among 160 in total and is led by Altbach and Yonezawa. The scholars in this cluster are correlated with internationalisation concepts, rationales and frameworks in this domain. (e.g. Rumbley, Byay, Huang, Cummings and Teichler). They have reached a consensus on the concept, meaning, trends, goals and content of the internationalisation of 


\section{HEED 15,1}

Figure 6.

Author co-citation analysis

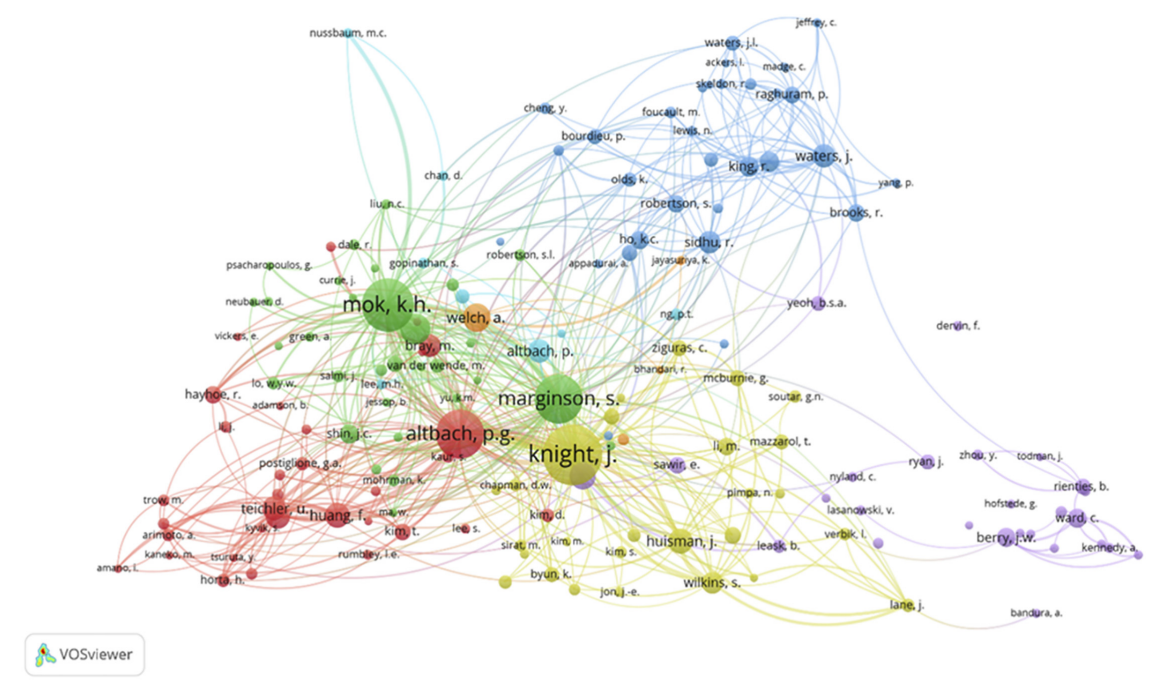

higher education. In addition, Huang and Hayhoe have focused on Japanese and Chinese higher education and universities.

The green cluster in the centre, led by Mok and Margison, is correlated with the growing influence and impact of rankings on higher education. Global rankings nurturing research on higher education internationalisation in Asia has become "a barometer of global competition measuring the knowledge-producing and talent-catching capacity of higher education institutions" (Hazelkorn, 2009, p. 47). The strategies and challenges of establishing world-class universities have drawn great attention among Asian higher education (e.g. Mohrman, Salmi and Hazelkorn).

The yellow cluster, led by Knight and Huisman, includes the scholars who are highly concerned with the trends and development of international branch campuses (e.g. Huisman, Wilkins and Kinser), as well as quality assurance (e.g. Hou, Mcburnie and Byun). With the international branch campus being a rising phenomenon in Asia, the motivations and policies of universities have become important research foci in Asia.

The blue cluster at the top of the map, led by Waters, Sidhu and Collins, is heavy on explorations of the motivations and meanings of international student mobility and migration. Scholars in this research stream have used empirical research methods such as questionnaire surveys, interviews and case studies to realise the impact of internationalisation and globalisation on international students from varying perspectives (e.g. King, Brooks, Bourdieu, Ho, Yeoh and Raghuram).

The purple cluster, led by Berry and Ward, comprises scholars correlated with the internationalisation of curriculums. Scholars such as Ryan and Leask studied the disciplines and innovation of curriculums and argued that the internationalisation of a curriculum should be a well-planned, constantly developing and cyclical process (Leask, 2013).

The light blue cluster is concerned with educational policies. Universities must have the support of relevant international education policies to realise the goal of long-term development and internationalisation. Scholars such as Altbach, Hallinger and Gopinathan have cared about leadership challenges in the process of internationalisation and have emphasised transnational entrepreneurial leadership. They conduct research that reflects on 
teaching and transformational leadership practice. Finally, the orange cluster, led by Welch, is associated with international activities and human capital structure.

\subsection{Topical issues and trends}

Keyword co-occurrence was analysed to determine the knowledge network and academic relationship between different topics and contents, which revealed the current research issues and trends in a domain. The analysis also highlighted the diachronic development and transformation of the research domain. Keywords can represent the main content of an article; as such, the frequency and co-occurrence of keywords can shed light on the focus of a particular field to a certain extent (Chen et al., 2016). As Zupic and Cater (2015) expressed, "When words frequently co-occur in documents, it means that the concepts behind those words are closely related" (p. 435).

First, 89 keywords were applied, and a minimum of three occurrences were set as a threshold (see Table 6). The results showed the distribution of the most co-occurring keywords were higher education (76 cases), internationalisation (31 cases), international students (30 cases), globalisation (29 cases), Asia (29 cases), student (26 cases), China (18 cases), university sector (17 cases), mobility (16 cases) and Malaysia (14 cases).

To some extent, our results revealed that the popular research themes in higher education internationalisation were as follows: Asian immigrant, migration, cross-border education and acculturation. These were followed by relatively new areas: Asian international students, transnational education, student mobility, international branch campus and regional case (referring to China, Hong Kong and Korea) (Figure 7).

\section{Discussion}

5.1 Who actually published most research of higher education internationalisation in Asia?

The regional distribution of publications reflects the degree of attention to higher education internationalisation research in different academic circles, which can be easily judged the location of international academic centers for higher education research.

\begin{tabular}{|c|c|c|c|c|c|}
\hline Keywords & Cluster & Links & Total link strength & Occurrences & \\
\hline Higher education & 4 & 73 & 251 & 76 & \\
\hline Internationalization & 6 & 37 & 78 & 31 & \\
\hline International students & 3 & 35 & 75 & 30 & \\
\hline Globalization & 2 & 51 & 130 & 29 & \\
\hline Asia & 1 & 45 & 102 & 29 & \\
\hline Student & 5 & 56 & 164 & 26 & \\
\hline China & 4 & 43 & 81 & 18 & \\
\hline University sector & 5 & 46 & 108 & 17 & \\
\hline Mobility & 7 & 37 & 84 & 16 & \\
\hline Malaysia & 3 & 24 & 38 & 14 & \\
\hline Education & 1 & 34 & 64 & 12 & \\
\hline Japan & 6 & 25 & 37 & 9 & \\
\hline International migration & 5 & 23 & 57 & 9 & \\
\hline Hong Kong & 4 & 29 & 52 & 9 & \\
\hline Education policy & 4 & 27 & 41 & 8 & \\
\hline East Asia & 2 & 22 & 37 & 8 & \\
\hline Academic performance & 4 & 26 & 37 & 7 & \\
\hline Quality assurance & 2 & 11 & 12 & 7 & Table 6. \\
\hline Korea & 3 & 14 & 16 & 7 & Top 20 co-occurring \\
\hline Transnational education & 3 & 19 & 28 & 6 & keywords \\
\hline
\end{tabular}


HEED

15,1

48

(1) Western nations

Not to our surprise, the USA, the UK and Australia are the top three countries publishing articles on higher education internationalisation in Asia, similar to other domains. They have formed a situation of tripartite confrontation. As the increasing Asian higher education market has become one of the strong competitors for international student recruitment, development in the internationalisation of Asian higher education inevitably attracted Western researchers' attention. In addition, scholars in Asian countries and regions, such as Hong Kong, Taiwan, China, Singapore, South Korea, Japan and Malaysia, have started to rapidly keep pace with the domain. Nevertheless, there was a gap of research outputs among countries. The most productive scholars are in East Asia, which might likely illustrate the unbalanced development of higher education internationalisation in Asia currently.

(2) Comprehensive universities

The authors of the 241 articles selected were from more than 100 universities around the world. As leading institutions, the University of Hong Kong, Hong Kong Institute of Education, National University of Singapore and Fu Jen Catholic University appear to have greater influences in the research domain in terms of citations and productivity. Authors from these institutions have significantly promoted the field, and their research often reflects the trending issues and directions of internationalisation research in higher education.

(3) Leading journals and Asian authors have been recognised

The concentration of paper publications reflects the development direction of higher education research. Three journals Higher Education, Studies in Higher Education and the Asia Pacific Education Review dominated the trends of the research. Among the top five leading authors, three of them are from Asia:Hou, A.Y.C. from Taiwan; Mok, K.H. from Hong Kong; and Yeoh, B.S.A. from Singapore. Asian scholars were frequently co-cited with authors from outside Asia, particularly New Zealand, the UK and the USA. They tended to work mainly with English-speaking countries.

Figure 7.

Temporal overlay on a keyword co-occurrence map for the internationalisation of higher education (2013-2018)
VOSviewer

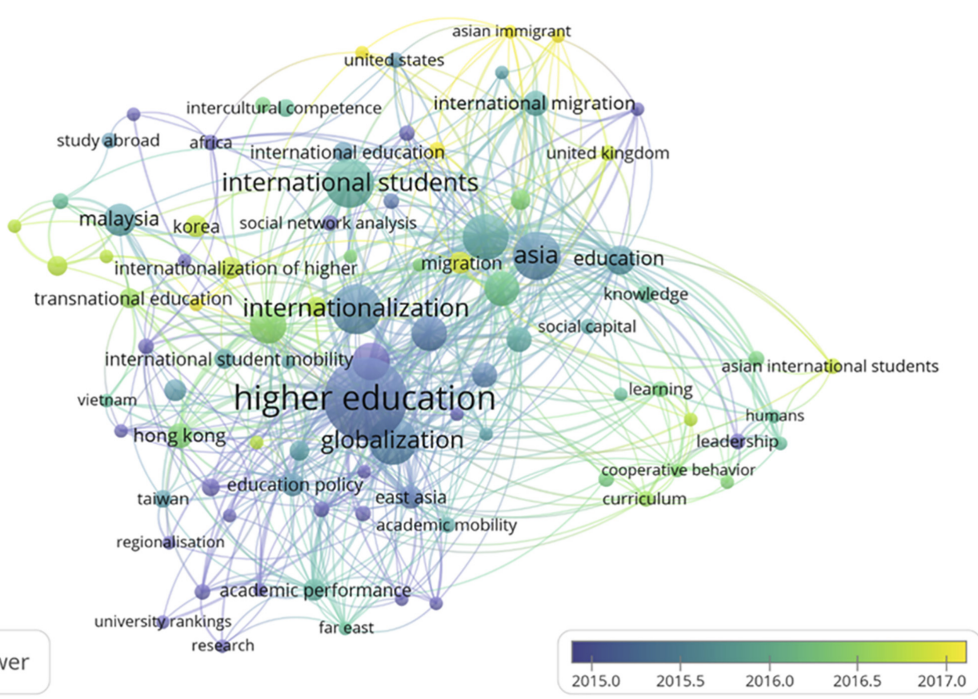


The study identified four major trends and groups of researchers in the future research in higher education. The first main trend was "Asian immigration and mobility". Ong et al. (1992) noted that "Asians emerged as a dominant group in the immigration of all professionals, from both the developed and developing nations" (p. 2). Numerous students have the motivation to study overseas, and a strong relationship between migration and education exists (Brooks and Waters, 2011; Dustmann and Glitz, 2011; Raghuram, 2013).

The second main research trend was "transnational education". Huang (2007) pointed out that "Asia is the most important and active region for participation in transnational education". In recent years, the internationalisation of higher education is no longer a simple flow of international students and academic staff, but it also includes activities such as the mobility of institutions and courses, online education, transnational projects and university coalitions (Huang, 2007; Kim, 2009).

The third main trend was "international students and acculturation". Brooks and Waters (2011) asserted that East Asia is the most important source of international students around the world. With the increase in the number of international students worldwide, acculturation stress is emerging as a critical concern (Shafaei et al., 2016). The process of adjusting to a new culture has become a core challenge for many individuals.

The fourth main trend focuses on "international branch campuses". Authors have studied and conceptualised international branch campuses and regarded them as the most intrusive forms of cross-border education, although they also considered them to be the least regulated. (Coleman, 2003). Studying the motivations and the decisions of universities to engage in the establishment of branch campuses overseas remains crucial.

\subsection{Lack of regional networking remains an issue}

Higher education internationalisation research is highly dependent on a small number of individual scholars, which represents regional cooperation in the current higher education research domain in Asia has not yet emerged. In other words, joint publications and regional networking among Asian researcher are still limited. The results revealed seven major academic clusters, with a number of high-yielded and high-cited scholars who have been crucial for developing the higher education internationalisation domain in Asia. As the key to higher education development success is the wider engagement of higher education researchers, Horta and Jung (2014) suggested that Asian academics need to actively participate in global and regional research networks to develop the cross-fertilisation of research ideas in the academic community.

\section{Conclusion}

This bibliometric review can predict the main trends in higher education internationalisation in the future and encouraged implication of interdisciplinary research in higher education internationalisation, although there is much more of the entire literature in higher education internationalistion than we described in this research. The result may only represent the articles written in English and from the SCOPUS database. However, the use of co-citation analysis mitigated the limitation. Finally, despite the quantitative rigor of bibliometrics, co-citation is a challenge. Zupic and Cater (2015) mentioned that to "understand" the output of co-citations and make analysis, scholars should have relatively solid literature knowledge.

Internationalisation places emphasis on international mobility and transregional development. Sharing common cultural characteristics and historical tradition, regional cooperation in higher education research should be strengthened. The present study 
HEED 15,1

suggests that trans-regional cooperation is the future of internationalisation in higher education. Asian scholars are recommended to increase cooperation and exchanges with each other, expand channels of contact, further understand and optimise their own advantages, achieve win-win cooperation and make Asia's voice heard in the world in the higher education field.

Besides research on learning outcomes, quality and social impacts on higher education internationalisation should deserve more attention in the future. As De Wit et al. (2015) stated, Internationalisation as "the intentional process of integrating an international, intercultural or global dimension into the purpose, functions and delivery of post-secondary education, in order to enhance the quality of education and research for all students and staff, and to make a meaningful contribution to society" (p. 3).

\section{References}

Altbach, P. (1999), "The perils of internationalizing higher education: an Asian perspective", International Higher Education, Vol. 15, pp. 4-5.

Altbach, P.G. (2002), "Perspectives on international higher education", Change: The Magazine of Higher Learning, Vol. 34 No. 3, pp. 29-31.

Altbach, P.G., Reisberg, L. and Rumbley, L.E. (2009), Trends in Global Higher Education: Tracking an Academic revolutionWorld Conference on Higher Education, The New Dynamics of Higher Education and Research for Societal Change and Development, Paris.

Bennell, P. and Pearce, T. (2003), "The internationalisation of higher education: exporting education to developing and transitional economies", International Journal of Educational Development, Vol. 23 No. 2, pp. 215-232.

Börner, K., Chen, C. and Boyack, K.W. (2003), "Visualizing knowledge domains", Annual Review of Information Science and Technology, Vol. 37 No. 1, pp. 179-255.

Bohm, A., Davis, D., Meares, D. and Pearce, D. (2002), Global Student Mobility 2025: Forecasts of the Global Demand for International Higher Education, IDP Education Australia, Melbourne.

Braam, R.R., Moed, H.F. and Van Raan, A.F. (1991), "Mapping of science by combined co-citation and word analysis. I. Structural aspects", Journal of the American Society for Information Science, Vol. 42 No. 4, pp. 233-251.

Brooks, R. and Waters, J. (2011), Student Mobilities, Migration and the Internationalization of Higher Education, Palgrave Macmillan, Basingstoke.

Chen, X., Chen, J., Wu, D., Xie, Y. and Li, J. (2016), "Mapping the research trends by co-word analysis based on keywords from funded project", Procedia Computer Science, Vol. 91, pp. 547-555.

Cobo, M.J., López-Herrera, A.G., Herrera-Viedma, E. and Herrera, F. (2011), "Science mapping software tools: review, analysis, and cooperative study among tools", Journal of the American Society for Information Science and Technology, Vol. 62 No. 7, pp. 1382-1402.

Cobo, M.J., López-Herrera, A.G., Herrera-Viedma, E. and Herrera, F. (2012), "SciMAT: a new science mapping analysis software tool", Journal of the American Society for Information Science and Technology, Vol. 63 No. 8, pp. 1609-1630.

Coleman, D. (2003), "Quality assurance in transnational education”, Journal of Studies in International Education, Vol. 7 No. 4, pp. 354-378.

Collins, F.L., Sidhu, R., Lewis, N. and Yeoh, B.S. (2014), "Mobility and desire: international students and Asian regionalism in aspirational Singapore", Discourse: Studies in the Cultural Politics of Education, Vol. 35 No. 5, pp. 661-676.

De Wit, H., Hunter, F., Howard, L. and Egron-Polak, E. (2015), "Internationalisation of higher education", The Bloomsbury Handbook of the Internationalization of Higher Education in the Global South, London, p. 23. 
Dustmann, C. and Glitz, A. (2011), "Migration and education", Handbook of the Economics of Education, Elsevier, Vol. 4, pp. 327-439.

Gacel-Ávila, J. (2005), "The internationalisation of higher education: a paradigm for global citizenry", Journal of Studies in International Education, Vol. 9 No. 2, pp. 121-136.

Ghasempoor, A., Liaghatdar, M.J. and Jafari, E. (2011), "The internationalization of higher education: an effective approach for Iran higher education", Higher Education Studies, Vol. 1 No. 2, pp. $35-40$.

Hazelkorn, E. (2009), "Rankings and the battle for world-class excellence", Higher Education Management and Policy, Vol. 21 No. 1, pp. 1-22.

Horta, H. and Jung, J. (2014), "Higher education research in Asia: an archipelago, two continents or merely atomization?", Higher Education, Vol. 68 No. 1, pp. 117-134.

Houshmand, S., Spanierman, L.B. and Tafarodi, R.W. (2014), "Excluded and avoided: racial microaggressions targeting Asian international students in Canada", Cultural Diversity and Ethnic Minority Psychology, Vol. 20 No. 3, p. 377.

Huang, F. (2007), "Internationalization of higher education in the developing and emerging countries: a focus on transnational higher education in Asia", Journal of Studies in International Education, Vol. 11 Nos 3-4, pp. 421-432.

Hudzik, J.K. (2011), Comprehensive Internationalization: From Concept to Action, NAFSA: Association of International Educators, Washington, DC.

Jon, J.E., Lee, J.J. and Byun, K. (2014), "The emergence of a regional hub: comparing international student choices and experiences in South Korea”, Higher Education, Vol. 67 No. 5, pp. 691-710.

Jung, J. and Horta, H. (2013), "Higher education research in Asia: a publication and co-publication analysis", Higher Education Quarterly, Vol. 67 No. 4, pp. 398-419.

Kehm, B.M. and Teichler, U. (2007), "Research on internationalisation in higher education", Journal of Studies in International Education, Vol. 11 Nos 3-4, pp. 260-273.

Kim, T. (2009), "Transnational academic mobility, internationalization and interculturality in higher education", Intercultural Education, Vol. 20 No. 5, pp. 395-405.

Knight, J. (1993), "Internationalization: management strategies and issues", International Education Magazine, Vol. 9 No. 6, pp. 21-22.

Knight, J. (2003), “Updated definition of internationalization”, International Higher Education, No. 33.

Leask, B. (2013), "Internationalizing the curriculum in the disciplines-imagining new possibilities", Journal of Studies in International Education, Vol. 17 No. 2, pp. 103-118.

Marginson, S. (2011), "Imagining the global", in King, R., Marginson, S. and Naidoo, R. (Eds), Handbook on Globalization and Higher Education, Edward Elgar, Cheltenham, pp. 10-39.

Mok, K.H. (2007), "Questing for internationalization of universities in Asia: critical reflections", Journal of Studies in International Education, Vol. 11 Nos 3-4, pp. 433-454.

Mok, K.H. and Yu, K.M. (2013), Internationalization of Higher Education in East Asia: Trends of Student Mobility and Impact on Education Governance, Routledge, London and New York, NY.

Morris, S.A. and Van der Veer Martens, B. (2008), "Mapping research specialties", Annual Review of Information Science and Technology, Vol. 42 No. 1, pp. 213-295.

Nerur, S.P., Rasheed, A.A. and Natarajan, V. (2008), "The intellectual structure of the strategic management field: an author co-citation analysis", Strategic Management Journal, Vol. 29 No. 3, pp. 319-336.

Ong, P.M., Lucie, C. and Evans, L. (1992), "Migration of highly educated Asians and global dynamics", Asian and Pacific Migration Journal, Vol. 1 Nos 3-4, pp. 543-567.

Palmer, J., Roberts, A., Cho, Y. and Ching, G. (Eds), (2011), The Internationalization of East Asian Higher Education: Globalization's Impact, Springer, New York. 
HEED 15,1

Postiglione, G.A. (2011), "Global recession and higher education in eastern Asia: China, Mongolia and Vietnam”, Higher Education, Vol. 62 No. 6, pp. 789-814.

Raghuram, P. (2013), "Theorising the spaces of student migration", Population, Space and Place, Vol. 19 No. 2, pp. 138-154.

Rienties, B., Héliot, Y. and Jindal-Snape, D. (2013), "Understanding social learning relations of international students in a large classroom using social network”, Higher Education, Vol. 66 No. 4, pp. 489-504.

Shafaei, A., Nejati, M., Quazi, A. and von der Heidt, T. (2016), "When in Rome, do as the Romans do'Do international students' acculturation attitudes impact their ethical academic conduct?", Higher Education, Vol. 71 No. 5, pp. 651-666.

Shin, J.C. and Harman, G. (2009), "New challenges for higher education: global and Asia-Pacific perspectives", Asia Pacific Education Review, Vol. 10 No. 1, pp. 1-13.

Sin, S.C.J. (2011), "Longitudinal trends in internationalisation, collaboration types, and citation impact: a bibliometric analysis of seven LIS journals (1980-2008)", Journal of Library and Information Studies, Vol. 9 No. 1, pp. 27-49.

Streitwieser, B. and Ogden, A. (2016), "International higher education's scholar-practitioners: bridging research and practice", in Symposium Books, Didcot, Oxford.

Van Eck, N. and Waltman, L. (2010), "Software survey: VOSviewer, a computer program for bibliometric mapping”, Scientometrics, Vol. 84 No. 2, pp. 523-538.

van Eck, N.J. and Waltman, L. (2017), "Citation-based clustering of publications using CitNetExplorer and VOSviewer”, Scientometrics, Vol. 111 No. 2, pp. 1053-1070.

Wang, J. (2015), "University internationalization-the internationalization of higher education in Asia", Shanghai Education, Vol. 26, pp. 16-21.

Yue, C. and Liu, Z.Y. (2005), "The atlas of Scientific knowledge”, Studies in Science of Science, Vol. 23 No. 2, pp. 149-154.

Zupic, I. and Čater, T. (2015), "Bibliometric methods in management and organization”, Organizational Research Methods, Vol. 18 No. 3, pp. 429-472.

\section{Further reading}

David, M. and Naidoo, R. (Eds) (2013), The Sociology of Higher Education: Reproduction, Transformation and Change in a Global Era, Routledge, London.

Jane, K. (2003), "Updating the definition of internationalization", International Higher Education, Vol. 33, pp. 2-3.

Park, J. (2018), "Public fathering, private mothering: gendered transnational parenting and class reproduction among elite Korean students", Gender \& Society, Vol. 32 No. 4, pp. 563-586.

Teichler, U. (2004), "The changing debate on internationalisation of higher education", Higher Education, Vol. 48 No. 1, pp. 5-26.

\section{Corresponding author}

Yang Can can be contacted at: connieyang51@163.com

For instructions on how to order reprints of this article, please visit our website:

www.emeraldgrouppublishing.com/licensing/reprints.htm

Or contact us for further details: permissions@emeraldinsight.com 